\title{
父，坂口謹一郎・人と業績と (1)
}

わが国の醸造学・酘酵学に, いち早く生化学的視点を導入して「応用微生物学」を発展させた偉大な先覚 者 坂口謹一郎先生。醸造に携る者にとって, 決して忘れられない存在ではあるが, 先生が東京大学教授を 退官されてから約半世紀, ご逝去から早 10 年。先生から直接ご薫陶を受けた多くの先輩諸氏も既に第一線 を退かれた。

本誌第 100 巻に当たり, 醇造学・酒学の大恩人である先生に最も間近で接してこられたご子息に「人間・ 父坂口謹一郎」を語っていただいた。

\section{坂 口健 二}

\section{| プロローグ}

私に最大の影響を与えた人物は，と問われれば，恥 ずかしいことですが，「父の坂口謹一郎です」と答え ざるを得ません。76才となった今, 私自身の決算の ひとつとして, 私の人生に大きな影響を与えた父, 謹 一郎の人となりと業績を私の視点から語ってみたいと 思います。

父は, 平成 6 年 12 月に 97 才で亡くなりましたが, 今生きていれば 108 才になります。今や直接会った 方々も少なくなり，伝説の人になりつつあると感じま す。

\section{（1）坂口謹一郎の業績}

謹一郎は頭のよい人でした。それだけに，どうしよ うもない苛立ち, 怒り, 我慢を要することもしばしば で, それが原因となり, 大学や家庭, 周囲の人々に恐 怖感を与えていた。視点を変えれば, 一人の凡夫であ ったと思います。

有り難いことに, その有能さについては皆さんが認 めて下さり, 多くの挮子, 同僚, そ机に加えて他の 大学, 研究所にも刺激を与えつつ, わが国の優れた応 用微生物学を, これらの方々と力を合わせて築きあげ た男といえるでしょう。改めて申寸までもなく，わが 国の応用微生物学は, 数ある日本の科学分野の中で, 外国より優れているものの一つとして, 内外が認める ところでしょう。このようにして隆盛をみた応用微生

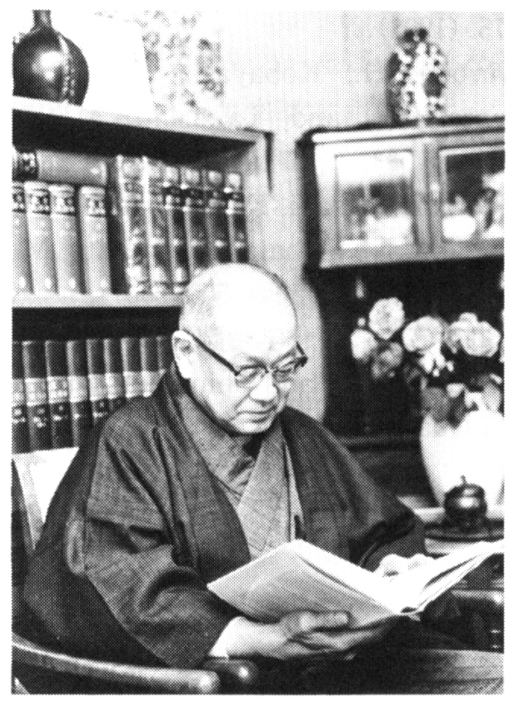

写真 170 才の頃

物学一自然界から有用な微生物を探し, 人間の役に立 たせる学問一も, 昨今は分子生物学の興隆にともなっ て, いささか陰りを感じさせられるように思えること は残念なことです。

遺伝子工学の手法を使って生物の本質を探究するの は大いに結構なことですが, その応用である分子育種 (このことばは, 1976 年頃に私が作ったもの) は, 手 法としては既に確立しています。したがって,これか らは, 今まで研究できなかった高熱環境や深海環境か

Kin-ichiro Sakaguchi, His Life and Achievements (1)

Kenji Sakaguchi (Councillor, Japan Society for Bioscience, Biotechnology and Agrochemistry) 
ら有用微生物を探し出したり, あるいは現在純粋培養 できない微生物（地球上の微生物の $97 \%$ はこれであ るという）の中から有用な能力を持つ微生物を探し出 し，それに遺伝子工学的手法を応用することによって， さらに人類の役に立つ科学を創造するのはいかがでし ようか。

話は横に逸れたが, 謹一郎の業績の abstruct や著 書を改めて読んでみると，その生涯は 3 つに分けられ る。1つは応用微生物学者としての学問的業績で, 2 つ目は，管理者としての能力。 3 つ目は，趣味人とし ての謹一郎で, 短歌, 俳句の創作と陶磁器の鑑賞。そ れに，酒を仲立ちに友人，門下の方々と温かい交流を 続けた，ということになります。これらは，彼の年齢 的な段階と大体一致していますが，その業績を概観し ながら，彼のあらゆる考え方の根底をなす生い立ちと 家族関係についてもふれたいと思います。

\section{(2) 酒学・酻造学と謹一郎の係わりあい}

謹一郎は日本酒・味噌・醬油の研究を根底とするわ が国独自の発醉学, 醸造学に生化学を持ち込んだ先覚 者であるとともに，アルコール発酵をはじめとする夕 ンク培養による発酵工業の推進者であり, わが国の発 酵工業に貢献したと思います。

謹一郎が恩師, 高橋偵造教授から頂いた最初のテー マは「リゾープスによる有機酸発酵」であり, コハク 酸, フマール酸, リンゴ酸などのジカルボン酸類をレ ゾルシンを使った鋭敏な発色試薬によって検出しなが

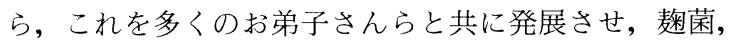
酵母, Bacterium succinicum などにも応用し, 後に TCA cycle として知られる経路，すなわち $\mathrm{C}_{2}$ 化合物 (Acetyl-CoAの Acetyl 基に相当する) から各種有機 酸ができることを推定しました。

このような生化学的研究を農学部で始めたものだか ら, 理学部などからは「百姓生化学」と挪揄され, 口 惜しい思いをした，と後年語っていました。独創的ゆ えにそんな言われ方をしたのでしょう。大正 13 年に 日本農芸化学会が発足して「自分たちの研究が自由に 発表できるようになった時の喜びは，今の人間には理 解できまい」とも時おり聞かされました。いずれにせ よ, 謹一郎の生化学は日本独自の発酵学, 醸造学に根 ざしたものであったと思います。

このような学問の礎をわが国に植え付けてくれたの は, 当時の外国人教師，つまり抢雇い教師です。若く
て優秀な人々を多数，ドイツなどから招聘し，彼らに 総理大臣に並ぶ高給を払ってくれた明治藩閥政府の大 功績の一つであると思います。

農芸化学ではケルネル（明治 13 年〜 24 年）が植物 生理化学, 土壌学, 肥料学, 家畜栄養学, 農産製造学 を拓き，これをロエブが継いだ。ロエブは微生物学の 分野で Sarcina，日本酒の麹菌，酵母，牛乳の乳酸菌 などの研究を，ケルネルについて学んだことのある古 在由直先生といっしょに行った。これを継いで日本酒 醸造の研究を精力的に展開したのが高橋偵造先生で, さらにこの流れを継いだのが坂口謹一郎です。

このように，わが国の応用微生物学は，日本酒など わが国独自の醉造に関わる微生物を分離し，その役割 を生化学的に研究し, これを人類のために役立てるこ とを目的に進められた。外国の理論や教説を学び, 追 いかけることを主流にせず，研究のシーズをわが国固 有の醸造に求めた実学精神が息づいている。したがっ て，ややもすれば外国から学んだ理論が先行するわが 国の科学が陥ち入った欠陥から免れたことは非常に幸 いなことだったと思います。このために後年，わが国 の応用微生物学は世界に冠たるものになったのだと思 います。

\section{II 謹一郎の生い立ちと人格形成の根底にひ光む もの}

ここで, 䔆一郎の出生から生い立ちにふれながら, 謹一郎の考えの基礎を形成しているものを述べさせて 頂こうと思います。

\section{（1）出生と幼少年時代}

謹一郎は明治 30 年 10 月 23 日, 新潟県高田町, 今 の上越市の, 鍋屋町 45 番地に, 父正利, 母マツの長 男として生まれました。ただし，この場所は市内にあ る控え屋の所在地で，「ここで乳母や女中にかしづか れて育った」のであり，実際に生まれたのは稲田橋 （妙高山から流れ出る関川に今でも架かっている）の たもとの河川敷にあった坂口製油所本屋の二階らしい。 坂口製油所とは，祖父七平と父正利がここで始めた製 油所で，地主の道楽商売のようにして近所から涌出す る少量の原油からランプ用の灯油を造っていた。一時 は原油を北海道からも取り寄せるなど，羽振りがよか ったが，その頃は未だ自動車など無いため，副成する ガソリンの用途がなく, 缶に詰めて放っておくか捨て 
ていた。これが後日に災厄を招くことになる。

ところで, 謹一郎の母マツの父七平は祖父の立場で 坂口家へ養子として入ってきたのだが, 謹一郎の父正 利との間には軘軪もあった中で，両家和合の証として 正利とマツが結婚し，二人の間に最初に生まれたのが 謹一郎であった。したがって, 謹一郎は両家和合の象 徵であり, 三段重ねの座布団に座らされる程に大事に された。加えて, 幼時から少年期を地主の御曹司, 総 領息子として, ぞこへ行っても下へも置か㚫いを受 けて過ごした。そして, 高田のお坊ちゃん学校である 高田師範付属小学校から高田中学へと進んだ。しかし, 中学校へ入学後, 二, 三か月して小児麻痺を患い, 一 夜にして足が立たなくなった。もちろん学校へは行け ない。そして, ぞうにか歩けるようになるまでに三年 もかかった。復学しょうにも同級生は既に四年生。謹 一郎は一年生として復学するのはいやだった。

このような生育歷が謹一郎の根本的な性格を形成し ている。謹一郎は, 周囲の人たちが皆自分を第一に考 え，遇してくれないとすこぶる不愉快になる。謹一郎 と酒席を共ににされた方々の中にもこのような彼の性 格を首肯される方も多いはずである。一方, 異常なま での小心さ, 用心深さは頭の良さとともに謹一郎の天 性のものでした。このような性格は, 一方で, 謹一郎 の経験した苦労とともに, 謹一郎の長所を形成してい ると思われる。彼は多くの人々の抢役に立った人だっ たが，その心の細やかさと情愛はこのようにして育ま れたのではないかと思う。

\section{（2）坂口家とは}

坂口家には代々伝わる由緒書なるものがある。これ は江戸末期に捏造したものらしいので笑い話になるが， 「坂口家は応神天皇より出づ…」に始まり, その後は 源平時代，戦国時代に飛び「信州更科に居住せる坂口 筑後なる者, 村上義清に属し，上杉謙信を頼って春日 山城に仕えた」となる。信州に居たのは事実らしく, 更科の冠木山の麓には今でも坂口姓の人久が居られる らしい。拙宅には代々伝わる聖徳太子像があり，信州 で兄弟が別れたときの片身分けであるとの言い伝えが あり，これを謹一郎が国立博物館に鑑定を依頼したと ころ，鎌倉期のものとのことで，見事に修復までして くださった。残念なことには, 冠木山の坂口家には残 っていないという。元来, 越後には信州からの移住者 が多い。
坂口家は代々頸城村字中城新田の地主で, 天和 （1681～1683）の頃から住んでいた。大肝煎りであり, 天和検地の庄屋でもあって, 名字帯刀を許されていた ことが父の自慢のひとつであった。お手継ぎさんと称 する当時の菩提寺は, 長い間 $30 \mathrm{~km}$ も西へ離れた吉 川町の小高い丘陵地帯にある中條という地の専徳寺で あり, その寺には坂口家が寄進した江戸時代のはりま ぜの名家の短冊の㺟風などが残されて抢り, 以前は中 條に郷士兼百姓として住んでいたと思われる。

ところで, 現在の頸城村は 20 年ほど前までは大瀁 村であり, 付近の大潟村, 犀潟などという名前からし て，この地域は湿地带であった。それを高田藩 45 万 石の松平光長（家康の六男忠輝の孫）の家老小栗美作 守とその子掃部が当代随一の土木家で高瀬川を堀削し た角倉了以を京都から招いて暴れ川であった保倉川の 屈曲した河口を真っ直ぐにし, 関川に直接流れ込むよ うに治水して, 広大な湿地带を干拓して美田とした。 今でもこの近傍の部落名に「中城新田」「鵜ノ木新田」 など, その名残がある。この時代に坂口家は吉川町の 丘陵地から平地の頸城村中城に移ったものと考えられ る。

余談になるが, その後, 小栗親子は歌舞伎の「越後 騒動」のモデルとなったお家騒動の張本人とされ, 切 腹させられ, 藩主光長も伊予松山藩に打預け, 松平藩 は取り潰しになる。この高田藩 45 万石の取り潰しの 遠因は, 藩祖忠輝が外様の大藩で幕府が常に警戒を㐭 らなかった仙台伊達藩から嫁を迎えたからと思います。 その後, 高田藩は美作の津山から親藩である榊原家が 15 万石で封ぜられ，加賀百万石の抑えとなって明治 に至っている。江戸時代の㧍家騒動の多くは, 経済推 進派と守旧派の抗争と思うと理解できると思います。

\section{（3）家運の衰退}

坂口家に養子に入った曾祖父の七平は，なかなかの 実業家であり, 明治 20 年頃に起こした坂口製油所は アメリカ製の最新鋭蒸留機を備えた先端工場で，東京 帝大の先生が学生をつれて見学に訪れたほどでした。 また，鍋屋町には鉄工所と澱粉製造業。北海道の裏夕 張には油田，札幌には貯油所を持ち，それぞれの事業 所に一族を配していた。しかし，前にもふれたように 当時は廃棄物であった揮発油（ガソリン）を一斗缶に 入れて，ハンダで封をするために近くで炭火を焚くの で，その火が揮発油に飛び火してたびたび火事を起こ 
した。小学校にいる謹一郎に先生が，「おい坂口，ま たおまえの家が火事だぞ！，帰れ」と言われたという。

それに加えて，人の良い父正利は他人の借金の保証 人となり，結果的にその借金を被ることが多かった。 また，気位の高い七平や父正利は帝国石油が開業した 頃に申し込まれた提携を断り，後日これを悔やんでい たという。このようなことが重なり，家運は謹一郎が 小学生であった頃から急に傾きだしたが，電灯に代わ ろうという時代に, 灯油事業はいずれ消え去る運命に あったのだろう。このようにして, 石油精製業による 家業は衰退した。

\section{（4）一家の離散と居候}

家・屋敷, 田畑は次々に人手に渡り, 父正利が，そ して母マツも北海道へ行ってしまった。しかし，謹一 郎には「この子は見所があるから，高田で勉強させた い」という父の計らいで何とか学業は続けられた。苫 小牧で代書屋をやってた父が「これは私の道楽と思っ てくれ」といって, 謹一郎の学費を細々と送り続けた という。このような中で, 謹一郎は内気で臆病な少年 に育っていった。当時の愛読書は「通俗三国志」「水 浼伝」「八犬伝」などであった。同時に心にしみ込ん だニヒリズムも相当なもので，「ものごとは，どうせ なるようになる」という諦念感がいつも根底にあった。 つまり，二ヒリズム的なひねくれはなく，ニル・アド ミラリに近く，また何事かに憧れるというようなこと もなかった。特に，何かになりたい，あ〉いう人にな りたい，ということもなかったという。

後年, 易経にある「天行は健なり」という言葉を好 み, 三島海雲さんに揮毫して頂き, 額にして部屋にか けていた。私の「健二」という名前も，私が生まれる 前に脚気で幼死した兄をふまえて，「どうにでもなれ， と思わなくてはならない。という自分への戒めの言 葉だったのだと解釈している。父は, ミッチェルの 「風とともに去りぬ」のスカーレットの最後の言葉 「明日は明日の風が吹く」というのが俺の気分だ，と よく言っていた。

\section{（5）親戚の下宿から東京神田の順天中学へ}

学業は, 足が動かない 3 年間も通信教育を充分に受 けていたので，四年生に試験編入してくれる東京の順 天中学に進むことになった。母方の親戚である東京の 笠松さん宅へ移ったが，居候が下宿人へ変わっただけ で，特別の感慨はなかったという。当時の順天中学は
相当の不良中学だったらしく, 白鞘の短刀を持ってい ないと幅が利かず，謹一郎の抦に彫物がある刃渡り $20 \mathrm{~cm}$ くらいのものが家に残っていた。また，当時は ぞこの中学でもやっていた軍事教練があり，100人ほ どの悪童たちが銃をカメラに向かって構え，端にドス のきいた顔の坂口中隊長がサーベルを肩に構えた写真 も残されている。

このような中学生活では,「生来の人嫌い」もあっ て，これといった親友もおらず，神田の古本屋街で新 本・古本を買いあさって乱読生活を過ごした。白樺派 の影響で，トルストイやドストエフスキーなども読ん でいたが，後年に語ったところでは，自然派が好きに なり，借金に追われながら人間をあるがままに描いた バルザックのゴリオ爺さんなどは，越後の農民成金の 彼に似ている，面白い，などと言っていた。

大正期のその頃は，デカダンなる語が一世を風靡し ていて，気ままと頽廃の中にこそ真実があり，尊ぶと いう風潮であった。謹一郎の根本にも，この気分は強 くあり，後年，坂口安吾の堕落論などに「これはい い」と同感していた。

\section{（6）謹一郎と仏教}

また，仏教に対する興味も強まっていった。元来， 北陸から越後は浄土真宗の盛んな地であり, 宗祖親鸞 が配流された当時の越後国府の竹ノ内草庵，小丸山別 院などが高田にほど近い五智国府にあったことも影響 した一つであろう。坂口家には寺号もあり，その御本 尊の阿弥陀如来御像は厨子に納められて, 坂口家が北 海道を流浪した間も大切に帯同されていたが，それは 今これを書いている私の部屋にいらっしゃる。

謹一郎は中学四年の頃, 静岡県用宗の禅寺大雲寺に 夏を過ごし，申又ひとつの姿と托鉢姿の袈裟をまとつ た写真があり，自筆で「狇猴にして冠するのみ」との 賛が付いている。夏休みにたまたま大雲寺を訪れたく らいのことであったろうが，大学に入ってから，仏教 に関心が高まった。仏教に対する愛と帰依は謹一郎の 根本の一つで「親鸞は偉い人だよ」と常々語っていた。

当時謹一郎は, 遠縁の貴族院議員であった竹越与三 郎氏の夫人，竹代さんの勧めで，夫人が主宰する尼寺 観音庵での集会に熱心に通い，有名なお坊さんたちの 法話を拝聴する機会に恵まれた。竹越夫人はご自身が 読売新聞の女性記者のはしりで，この集会は 10 人ほ どの会であり，各宗にわたる多くの方々のお話を伺っ 


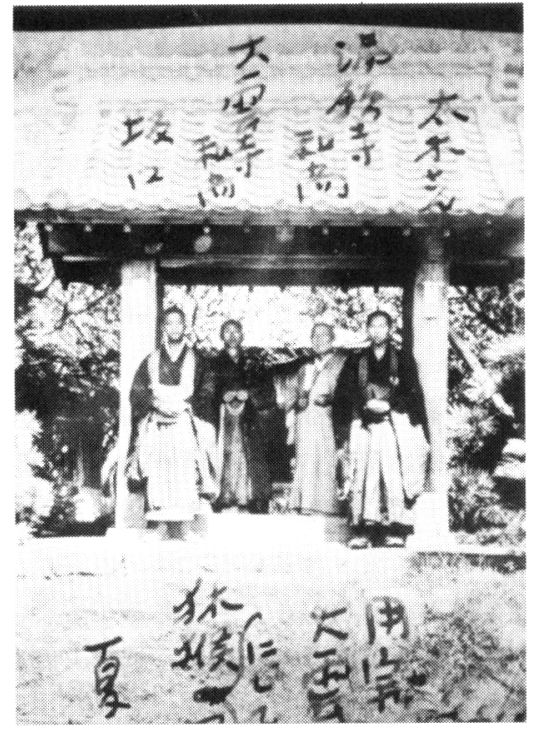

写真 2 「狇猴にして冠するの外」大雲寺にて

たらしい。唯識（認識論）の今津洪該先生や曹洞宗の 体験を語られた原田祖狩老師などから強い影響を受け, 仏典もかなり読んだようである。後年，謹一郎が結核 で転地療養したとき, 鋸山の日本寺の, 嘗って老師が 居室としておられた所を拝借したのもご縁であった。 さらに時が下って老師の没後, 謹一郎は若狭の発心寺 で老師の墓前に詣で，心から扔礼を述べたという。

「仏教の言うところは, 科学と矛盾しない。哲学的 な思索に耐える深い宗教である」と言っていたが, 「恒転如暴流」(煩悩や物質・生命のどうにも止められ ない流机の激しさ),「草木国土悉皆成佛」とか「五蘊 仮和合」(唯識の言葉で, 全ての生命, またこの世に あるものは，空無のエネルギーの仮に集まったもの) といった言葉が好きであった。

最晚年の十年は脳梗塞, 昔でいう中気で倒れ, 三 〜四年は床についていたが，床の間には昔から家にあ った野晒しの髑顝の絵がしばらく掛けられていた。そ の後は聖徳太子の拓本「唯佛是真」を見ていた。ただ, 悟りを開くにはあまりに遠く，臆病に死を怖がるのを 見か权て「少しは死生観を拓いたらどうだ」と私が言 うと，「とても俺にはそういうことはできない, ジ夕 バ夕しながら死奴のも悟りの一つだ」と言った。

\section{（7）一高に首席入学关して自由な寮生活}

第一高等学校は東大教養学部の前身だが, そこは全 寮制だった。いち抢う優秀と折り紙の付いた 16 才位
の男子のみを 12 人づつ一部屋に入れて「学校の勉強 はどうでもよいから古典を読め, 友人と切碰琢磨しな がら共同生活をせよ, 運動, 哲学なんでもやれ」とい うのだから,これ程自由な天地はなく, 若者にとって 一生忘れがたい人格形成を友人とともに過ごし, 将来 の方向を定めていく, 誰しもが熱く語る貴重な三年間 であった。また, 親から離れ, 独立したいという年頃 をうまく捉えており，全寮制の旧制高等学校は日本の 教育制度の中では最も成功したものと言わ机ているが, 同感です。

鳵山一郎元首相が一高に入ったとき, 教育者で任ず るご母堂が「一郎は家で教育したいから通学を許して ほしい」と校長に談判に行ったら,「本校の教育は寮 生活が根幹である，打嫌なら他校へどうぞ」と言われ， やむなく寮にはいったというエピソードがある。

一高の入学試験を受けた謹一郎の感想は「大変易し かった, 難関校がこんなに易しいはずはない。俺は落 ちたに相違ない」であり, 悄げかえって帰って来た。 生来の小心と臆病のなせるところであろう。ところが 発表前にある受験雑誌社の記者が来て「あなたはIII部 に首席で扔はいりになりました。といわれ，感想を 聞かれたが，何を話したか覚えていなかったという。 何でも漢文の問題では前に読んでいたものがそのまま 出たとかで,一人で勉強し, 乱読していたおかげであ ろう。当時,一高の理科は 3 部制で, I 部は理数系, II部は医科, そしてIII部が理・生物, 農科系であった。 I 部の首席は未綱怒一さんであった。ここで未綱さん はじめ多くの友人を持つことになる。愛知県知事を長 く務めた桑原幹根さんとは後に県の工業試験所設立に 協力し, 東レの種村功太郎さんや代議士の小金義照さ んなどはよく家に来られて楽しげに酒を酌み交わして おられた。寮では向かいの部屋にスポンジボールの名 手, 大佛次郎さん, 寮委員の同僚としては松隈秀雄 (大蔵省), 立花 馨 (銀行家), 松本俊一 (外務省か ら代議士）さんらがいた。コロイド化学の玉虫文一さ んは同室の美少年で「俺は彼を保護した」などと言っ ていた。

一高時代のもう一つの自己発見は「俺にもスポーツ ができる」ということだった。ある日上級生が教室へ 入ってきて，クラス一同を瞄み回したあげく，「揃 ちょつと来い」と謹一郎は有無を言わさずボート部の 漕ざ手にさせられた。私が小学四年生のとき, 榛名湖 


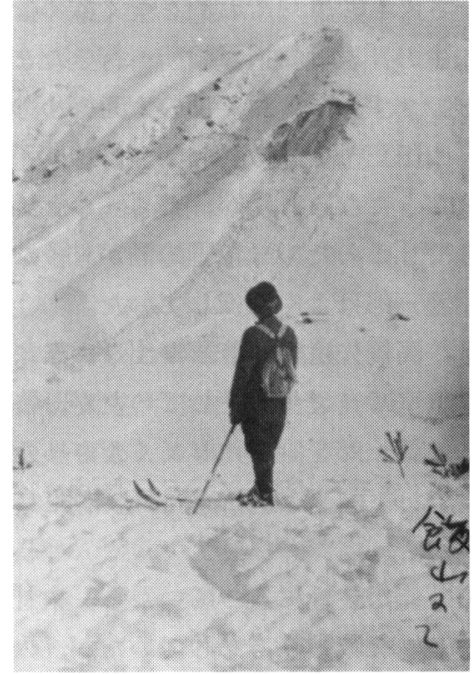

写真 3 雪の飯山にて

で，オールの先だけを水に浸す漕法を教えてくれたが, ボート部の経験によるものであったろう。ボート部の 練習は強烈で長くはやらなかったようだが，一方スキ 一の方は熱心で，三年間委員をやったり，部員を郷里 の高田の歩兵連隊に連れて行って，レルヒ少佐直伝の 荒っぽい山スキーをみんなに習わせたりした。また， 新潟県の赤倉温泉を本拠として山滑りに行ったりした。 猪谷千春さんの父である猪谷六合雄さんの「雪に生き る」という本に「気の早い一高辺りの学生が私が始め た頃には，スキーをやっていたらしい」とあるが，そ れが謹一郎のグループのことであったようだ。この頃 は軍隊用の実用的な山スキーが主体で, やらなかった ものはジャンプぐらいであったと話していた。

あまりにもスキーに熱心であったためか, 一高卒業 の翌年，大学に入ってからとうとう体をこわし，肺結 核を患った。これで完全にスキーとは離れることにな つた。

一高の寮では「友人はみなお坊ちゃんだったから， 寮の食事は不味い，不味いとこぼしていたが，居候だ った俺は何でも旨くてしょうがなかった」とよく話し， 母が卵焼きをつくっていると，「メリケン粉を入れろ， 入れろ!，一高の寮ではそうだった」といって母の嘖 歳を買っていた。このように, 謹一郎も一高時代には ボートやスキーをやり,さらには一高一三高戦の野球 の応援には京都へも出かけたり, 青春を謳歌した。
後年, 私が一高に入学し, 寮へ入ることになったと き，父は「金がかかるのだが，一生で一番楽しい時だ から，親の情けで入れてやる」と言い，「俺の一高の 帽子を取っておけば良かった」と不明を恥じるような 顔をした。

いずれにせよ, 一高生の頃は, 彼の人生最良の時代 だったらしい。

（8）大正八年, 東京帝国大学農学部入学

当時の一高は, 現在の東大農学部のところ, 旧水戸 藩邸にあり, 東大の農科は駒場で, 現在の東大教養学 部のところにあった。昭和 10 年に敷地交換して, 現 在のような姿になったのである。従って, 謹一郎は, 目白に下宿して駒場に通学した。

講義は面白くないので，ノートも丹念に取るわけで はなく，要点だけを大きな字で書いていた。試験は嫌 いだから,いつも真つ先に答案を提出して部屋を出て いく。したがって，成績はあまりよくなかったはずだ， と本人は言っている。しかし, 大きな字の要点を記し たノートは運動部の連中には重宝であったらしく，試 験の前には借りられてしまい, 肝心の自分が困ったと いう。武田義人さん（台湾総督府中研, アミロ法の研 究者), 渡辺八郎さん（国税局鑑定官）, 山田正一さん (醸造試験所長) などは, 家によく飲みに来られたが,

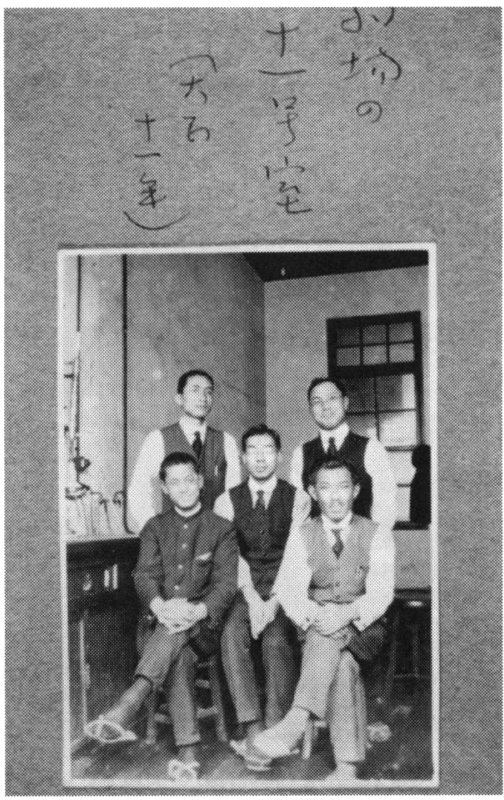

写真 4 研究室で, 高橋禎造先生を囲んで 
酔うと学生時代の話となり,「謹一郎は試験のヤマ賭 けが上手であった。武田さんは「そら出た，書け，書 け」という調子であったが，渡辺さんは「当たるもの か」といって，何時も損をしておった，といったこと が酒の看になった。

大学三年生になって, 卒論実験の指導教授として, はじめは鈴木梅太郎先生を考えていたが，一夕，山田 正一さんと高橋偵造先生宅を訪問し, 発酵学の将来性 を力説されて感銘, 山田正一さんとともに高橋教室に 入ることになった。鈴木梅太郎先生はこれを快く承諾 され，発酵学の重要性を語り，かえって激励されたと いう。このようにして, 謹一郎は発酵学と縁を結んだ。

高橋偵造先生はその頃, 酒造や醬油醸造の研究から 微生物の有機酸発酵, すなわち微生物生化学の方向へ 転換されようとしていた。高橋偵造先生から謹一郎に 与えられたテーマは「リゾープス属による有機酸発 酵」であり，どのような酸がどれほど生成されるか， というものだった。謹一郎はこのテーマを卒業論文と するとともに，さらに一年間研究を続けた後，大正 15 年に, 第一報を高橋先生との連名で発表した。こ の論文の原報は, 上越市の坂口蔵書として保存されて いる。

\section{（9）大正 11 年卒業, 高橋偵造教授の発酵学・醸造 学教室に入る}

当時の農芸化学の最も良い就職先はビール会社だっ た。製薬会社などに多く就職できるようになったのは， 発酵法によるペニシリンや他の抗生物質が盛んになっ てからのことである。謹一郎も貧乏であったから，キ リンか大日本ビール（アサヒ, サッポロ社の前身）に でも入ろうかと思っていたところ，「君の父上は未だ 若いのだから」と言って，高橋教授のお許しがでない。 その頃の高橋教授は，皆がごご機嫌とりに汲々とする ような気難しい先生だった。謹一郎も苦労をしたが, 後日，自分の思うことを通そうとするときは，逆にそ の反対の案を申し上げる。すると先生は「君，それは 違う。こうしなさい。」と意中の案を示された，とい う。

私が農芸化学へ入ったときには, 高橋先生はご病気 療養中であったが，父はやたら喜んで私を動坂の先生 宅へつれていってご挨拶した。先生の前で父は「鞠管 如」そのものであった。謹一郎を知っている皆さんに は，このような姿は想像もつかないであろう。
山田正一さんも，下戸でお酒を全く飲めなかったの に，高橋先生の「君は䁔造試験所へ行きたまえ」の一 言で反対もできず，泣く泣く酒の大元締めの試験所に 入られた。山田正一さんは長い間の修練で不思議とお 酒が飲めるようになられたが，どちらかというと甘い 酒が扔好きで「このために全国の酒が甘くなってしま った」と，謹一郎はよくこぼしていた。

謹一郎は，高橋先生の㧍許しが出ないまま，やむを 得ず発酵学教室で貧乏生活をしていたが，高橋先生は 卒業の年に，謹一郎を副手にしてくださった。そして， 大正 13 年には助手にして頂いたが，相変わらずの貧 そ生活だった。

父はよく「俺が会社に入っていたら，大社長になっ ていたぞ」と妙な威張り方をしていたが，人の気持ち はその人よりも先に判る方だし，先見の明はあったし， ことによるとその通りであたかも知れないと思う。大 会社には何時までも未練があったらしく，私が三菱化 成生命科学研究所の社宅に入ったら, 早速社宅を見に 来た。

\section{（10）平松子爵邸の寮長}

謹一郎が大学一年のある日, 校門のところに中年の 立派な婦人が立っていて，謹一郎の顔をマジマジと見 る。気にも止めずに教室にいると，事務室から連絡が あり，その婦人が会いたいとのことである。主旨は， 下宿に困っているなら，是非私のところへ来てくれな いか, ということであった。下宿料も安いので行って みると, 下馬の平松子爵邸という立派な邸宅で, 子爵 一家は軍務で朝鮮へ赴任して不在で，案内した先ほど のご婦人は平岡さんという女子学習院で歷史の先生を する傍ら，この邸宅の管理を任されている方であった。 洋館二階建ての立派な平松邸では, 三人の女中と料理 人，馬丁のついたままの居抜きだったので，訪れる同 級生からは「一生こんな生活はできないぞ」と羡まし がられた。

平松子爵は，頭山 満らの創立による玄洋社に関係 し，「アジアは一つなり」という考えから，数人のイ ンドその他の学生が部屋を借りていた。インド独立の 志士ボースさんなどが時々来て会合が持たれ，系車と 三色のインド独立の旗などもこっそり見せられたとい う。また，当時の「新しい女性」の集まりなどもあっ て，平塚らいてうさんなども見かけたという。 謹一郎は，この邸宅に二年半ほど住んだが，右翼の 
玄洋社は当時危険思想視され, 監視されていたらしい。 朝日新聞が嗅ぎつけ,「調べれぼ, 調べるほど判らな い」と面白しろ可笑しく「未亡人をめぐる学生たちの 魔の御殿」と二回にわたって書き立てた。謹一郎は平 岡さんと共に朝日新聞に抗議に行ったが有耶無耶にさ れ，こんな騷ぎで卒業試験にも出られず，口頭試験で 何とか通してもらった。

\section{（11）倉石カウとの結婚と結核}

大学での研究生活が始まった頃, 謹一郎は高田の陶 器店, 倉石昌吉とミカの長女 カウと結納した。力ウ の兄倉石文三郎には同級の清水正雄さん（明治製菓副 社長）の妹さんが嫁いでいる。カウは清水正雄さんに， 友人の中で唯一信頼できる人と言われたことを一生大 事にしていた。

ところが, 謹一郎は結納まもなく, 結核を発病して しまった。北海道にスキーに行った後，熱が下がらず， 過労から風邪だろうと思っていたのであったが。何し ろ当時の結核・肺病は死病といわれ, 転地療養くらい しか方法はない。謹一郎は婚約解消を申し入れたが, 儒学の家であった倉石家では，女がいったん決めた縁 談を解消するわけにはゆかぬといい, カウも一向に気 にせず，未婚のまま謹一郎の転地療養について行った。 謹一郎は, なかなか人にはできないことと感動し, も し, 一人であったなら完治したかどうか判らない, と 書いている。カウは当時の長岡女子師範学校を出て, 高田で小学校の先生をしていたが，何とかしてこの田 舎町をとび出したいという思いも強かったようだ。

転地療養先は, 千葉県館山市北条で, これも清水正 雄さんのお世話で, 清水さんのお姉さんの嫁ぎ先の隣 の家を借りて住むことになった。緊張した様子で，行 儀良く膝に手を置いて斜めに対座した，当時の二人の 写真が残されていた。

房総の陽光はすばらしく, 謹一郎の体調も徐々に快 復していったが，ここに大事件が起きる。大正 12 年 9 月 1 日の関東大震災である。館山は震源地に近かっ た。カウと謹一郎はいち早く外に飛び出し, 生け垣に 捕まったが左右に大きく摇れて捕まっていられなかっ たという。家はひとたまりもなく倒れたが，幸運にも 逃げ出した反対側に倒壊したので二人は助かった。清 水さんのお姉さんは, 逃げ出したもののその上に家が 倒壊し, 鴨居が落ちて後頭部に当たり亡くなられた。 それから半月ほど, 掘っ建て小屋で暮らした後, お姉
さんの遺児を背負って，船で東京へ戻った。東京でも 清水さんのお世話になっていたが, この家で, 謹一郎 と力ウはその年の十二月に清水さんの御父君の仲人で 形ばかりの結婚式を挙げた。

謹一郎はよく災害に会う人だった。佐渡では，汽船 が始まって以来という大シケにあっているし，東京空 襲のときは, 私は中学五年生で越後の家に一週間程に 柾開していたが，謹一郎は家政婦さんと二人で，焼夷 弾の火を井戸水をかけて消して回り，自分の家は焼け たのに隣家から先は火災を免れた。

\section{（12）倉石家のこと}

ここでカウの実家倉石家にふれておこう。もともと は高田の地主だが，天保の頃に江戸の安積良斎の門人 になった倉石典太が後年，高田に帰って私塾を開いた。 地主のご多分にもれず造り酒屋もやっていた。腐造が 続いて造り酒屋は廃業したが, その後は代々東本町で 「いせや」という陶器問屋を営んでいた。店の天井に は土瓶がたくさん吊してあり，カウら子供たちが二階 で騷いでは「土瓶が落ちる」と父昌吉に叱られたそう た。

父昌吉は明治初期, 福沢諭吉の門を吒き, 嘱望され ていたが，祖父の死去により家業を継がなければなら ず，志を捨てて泣く泣く高田へ帰つた。酒が大好きで 大酒を飲んだが，一夕酒に酔って溝に落ちてから晚酌 は一合と心に決めたものの, 夕方になると徳利を並べ

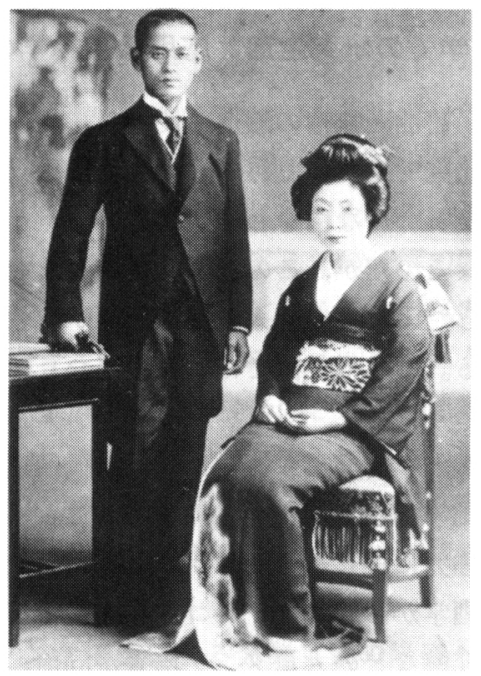

写真 5 結婚の記念写真 坂口謹一郎, 力ウ夫妻 
たりそそれを拭いたりしていた。よほど晚酌が待ち遠 しかったのだろう。カウはこの父にたいそう可愛がら れ，幼時から父の膝の上で晚酌の㧍相伴にあずかった ことを忘れなかった。

母ミカは学者風の人で, 源氏物語の講義をしたり, 孫の坂口ふみが東大に入ったとき「女も学問ができる ようになって，羡ましいねえ」とつくづく述懐した。 十二人もの子供を生み育てたが，大勢の子供たちは上 の者が下の子の世話をみる，喧㗆をしたら必ず上の者 が悪い, というのが信条で, 怒られるから兄弟姉林は 自然に喧嘩をしなくなった。カウも末妹の八重子の面 倒をよくみたが，妹に袂を垷まれている写真が残され ている。こんなわけで, 破産した石油屋の坂口家より, 倉石家は格が上と見られていた。

若い頃のある日，謹一郎は倉石家へ泊まったことが あり，その折りミカおばあさんから何か言われたこと に腹を立て，もう倉石の家には泊まらないと啖呵を切 ったそうだが，後日，結核を患い嫁にも行けず，家に

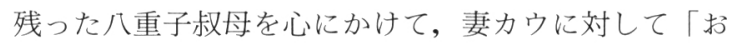
前が母代わりにならなくてはならないぞ」といい, 親 しくつき合ったうえ，財政的にも何かと面倒をみた。

倉石の兄弟は秀才揃いで, 太郎は東芝副社長, 武四 郎は中国文学の京大・東大教授といった具合だった。 しかし，既に皆鬼籍に入り，「いせや」は長いこと八 重子叔母が守っていたが, 今は黒御影石の碑がその跡 を留めるのみである。

\section{III 大学での研究生活と応用微生物学の形成}

日本酒, 醬油, 味噌の醸造に使われる錮菌や酵母, 乳酸菌の研究で始まったわが国の応用微生物学は, わ が国のオリジナルな菌をわが国独自の視点から研究す ることになるのだが，この外国のま悋をしない研究態 度は前述したように, 外人抢雇光教師から教元られた ものである。これは外国では研究の当たり前の原則だ つた。

謹一郎が大学を卒業する頃から, 高橋偵造教授のご 方針で生化学的研究の方向に舵を切ることになる。こ の方向を強力に押し進めたのが謹一郎だった。それと ともに, 酒学から離れてアルコール発酵やアセトンブ 夕ノール発酵などの大量タンク培養が同僚, 友人, 共 同研究者などによって研究され, 工業化されていった。 戦後は, 抗生物質発酵, アミノ酸発酵, イノシン酸発

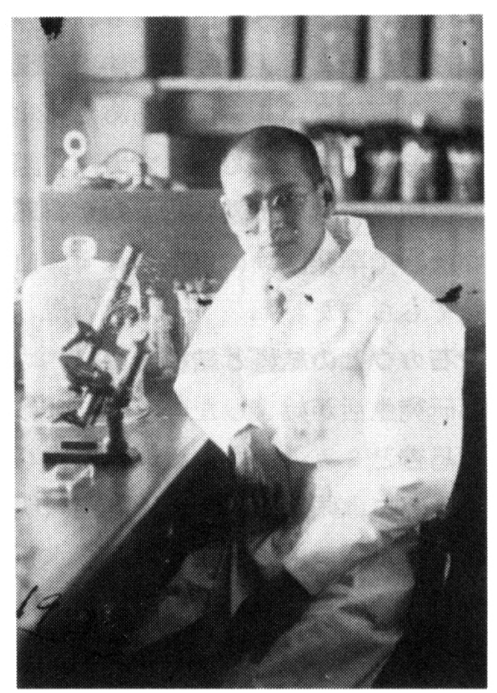

写真 6 研究室にて

「研究と結核の頃」

酵といった，わが国の発酵工業の全盛時代を築き上げ ることになった。日本の科学技術で外国に並ぶものは あるが,これを淩ぐものは他には無いのではないかと 思われる。

\section{（1）研究と結核と䞄乏と}

ここに一枚の写真があります。実験衣に身を包んだ 丸坊主刚りの鋭い目つきをした若き日の謹一郎です。 自筆で裏に「研究と結核の頃」と書かれている。結婚 前後の二年間の闘病生活で何とか大学に出られるよう になり, 研究を再開したが, 冬は風邪, 夏は胃腸を患 うという有様で, 夏は越後の海岸の安い借間で療養す るという生活を送った。私の小学一年生頃の記憶でも, 午前中は寝ていることが多く,「今日は大学へ行こう か, 行くまいか」といった状態だった。

貧乏も相当なもので, 妻のカウは正月の抢飾りは三 十一日の夜になって值下がりするのを待って買いに行 つた。一つのリンゴも二つに分けて食べた。後日, 母 は「あの頃がいちばん楽しかった」と述懐している。 散髪も庭に出て妻が謹一郎の頭をバリカンで丸刈りに した。私も小学二年生頃までは母に丸刈りにしてもら つていた。このような生活を支えたのは妻のカウであ つた。その中で謹一郎は妹の幸子を預かり, 賓しい中 で婚礼支度を整えてやり, 他家へ嫁がせた。謹一郎は 家計の足しにするために, 都立三商の夜学の先生をや 
っていたが，これがまた結核を悪化させる原因になっ た。加えて医者から酒を禁じられたため, くつろぐ方 法がなく，頭の鋭さだけが研ぎすまされて，周囲の研 究室の方々からは尊敬されると同時に大いに恐れられ ていた。昭和 2 年, 31 才で少壮助教授にして頂いた が，この頃から仲人の依頼もあり，数組の仲人をした ものの, 後日みな片方が亡くなるものだから, 本人も 「鬼がついているか」と気にして，その後長い間，仲 人は断りしていた。

\section{（2）趜菌などカビ類や細菌類が生産する有機酸類} の生化学的研究へ

先にもふれたように，高橋偵造教授からいただいた 卒論は「リゾープス属のカビがつくる有機酸」であっ たが，謹一郎は，当時としては鋭敏な呈色試薬である レゾルシン一亜硫酸一 $\beta$-ナフトールを使って分別定 量をおこなっていた。ジカルボン酸には鋭敏でそれぞ れの酸は異なる色で発色する。この方法で, フマール 酸，コハク酸，リンゴ酸，グルコン酸，ギ酸といつた TCA サイクルとペントースサイクルを構成する酸類 を定性することができた。液体クロマトグラフなど無 い当時の定性・定量分析は大変な根気・努力と熟練を 要するものであり，その方法は有機酸の塩を結晶化し， 標準品と混融して融点降下がおきるかどうかを調べる というものである。このような研究をとおして，リゾ 一プス菌には，エ夕ノールを多く生成する発酵型の菌 と，酸を多く生成する酸化型の菌があることに気づい ていた。また，リゾープス菌を嫌気培養した菌体から 当時はチマーゼと呼ばれていた酵素標品をとり，それ を用いてグルコースからエタノールを生成させること に成功している。さらに，リンゴ酸や酢酸からもこの 酵素標品を使ってエ夕ノールを生成できることを示し た。これは，当時としては画期的な研究であったと思 われる。リゾープス研究の第一報は大正 15 年の日本 農芸化学会誌第一巻に掲載された。昭和 3 年からは, 靝力ビの有機酸，エ夕ノール発酵を同じ方法で研究し， 先に掲げた各有機酸の他に，クエン酸，麹酸，蓚酸を 定量し，あわせて，掼菌には好気培養でも酵母よりも 多くエ夕ノールをつくる菌があることを知り, 驚いて いる。

これら一連の研究の結論は $\Gamma_{2}$ 化合物が基本とな って酢酸やクエン酸，コハク酸，エ夕ノールなどが生 成されると考えざるを得ない」，というものである。
$\mathrm{C}_{2}$ 化合物とはいわゆる Acetyl-CoA の acetyl 基に相 当するが, 昭和 7 年当時の学説としては, 全く突飛な ものであった。

謹一郎の考えは, このような生化学的な差異が分類 に使えるはずだ，いや使うべきであるということであ り，この考えにしたがって錮菌を好気生育種と嫌気生 育種とに分類した。この考えは形態的分類とは一致し なかったが, 同種のカビやバクテリアの中にも多くの 異なる性質の菌があることを知らせたことは価値ある ことと考えている。これはまた, 外国に先んじて, 自 然界から新菌株を分離することによって新しい発酵工 業を興すという学風をつくっていくのに大きな刺激を 与え, 後年のわが国の応用微生物学の隆盛の端緒を拓 いたものと思われる。

カビやバクテリア類のつくる有機酸とその代謝経路 の研究は, 謹一郎の初期のメイン・ワークであった。 これを通して多くの優秀なお弟子さんを育てる結果に なった。後日, 東大応微研所長になった朝井勇宣先生 の酢酸菌とグルコン酸菌の研究もその一つである。朝 井先生は私の恩師だが, 謹一郎とはウマが合い, 親し い交友が続いた。疎開先の新潟の百姓家の炉端で, 薪 の火を見つめながら, 楽しげに酒を酌み交わし, 民謡 を歌う姿が目に残っている。

当時, 朝鮮からの学生, 王 寅章 氏とのカビのた めの王・坂口培地や，グルタミン酸発酵の多田特許な ぞで有名な多田靖次さん（元玉川大学）とのコハク酸 をつくるバクテリアの研究, 後に合同酒精に行かれた 土井新次さんとのアミロ法によるアルコール生産, 謹 一郎が最も信頼して助教授にした馬場慎一郎さんとの 黒靝菌や他の力ビ類の有機酸生成とその生成経路の研 究，東北大学と東大の教授になった植村定治郎先生と の銤菌・バクテリアによるアミノ酸分解の研究, 東大 教授であった山田浩一さんによる靝力ビ群の形態学的 分類，同飯塚 廣さんによる電子顕微鏡による初めて の分類, 三楽酒造の尾崎浅一郎さんとの黒丧菌による クエン酸の工業的生産法等々で，枚挙にいとまがない。 昭和 13 年に謹一郎が頂いた日本農学賞の題名は「菌 類による有機酸類の生産ならびにその工業的利用に関 する研究」であった。

\section{（3）タンク培養による発酵エ業の隆盛へ向けて一 アミロ法による澱粉の糖化一}

麹蓋を使う固体培養は操作が煩雑で人件費もかかる。 
したがって, タンク培養で原料と菌とを一緒に仕込み， 培養しながら菌の生育と糖化を同時に行う方法はメリ ットが大きい。この方法の開発によって発酵工業は飛 躍的に発展することになった。この方法はリゾープス 菌によるタンク培養法として, 当時の仏領印度支那, 現在のベトナムで開発されたが, この大規模タンク培 養を可能にしたのが謹一郎の同級生で, 台湾総督府中 央研究所に抢られた武田義人さんと坂田さんらのグル ープであった。謹一郎は, 昭和 10 年頃からこの研究 所を度々訪れて共に研究していた。研究ついでに, 武 田さんらから酒を飲むことを教わり, それが自分の体 に合ったと見えて, 体重も増え, 日に日に結核がよく なっていった。現在でも使われているアミロ法による 甘藷などの糖化には，Rhizopus javanicus Takeda が 使われていると思うが, これはその当時の成果による ものである。この開発により, 日本の発酵工業は伝統 的な麹蓋法からタンクによる通気擋拌培養法に変わり, 近代発酵工業への道が拓かれ, 世界に一歩先んじるこ とになる。第二次大戦後に, ペニシリン発酵を工業化 するにあたって, 米国のフォスター教授は, わが国が 青カビのタンク培養をたちどころにやってのけたのに 驚いたそうだが，既に充分な素地と経験が積まれてい たわけである。

\section{（4）アセトン・ブタノール発酵}

わが国で，第二次大戦中にもう一つの大きな発酵工 業が生まれた。アセトン・ブタノール発酵である。こ れに使われたClostridium acetobutilicum 314 号菌は 坂口研究室で分離された菌である。ブタノールは飛行 機の燃料に使うガソリンのアンチノック剤に必要なイ ソオクタンを合成するために必要であった。坂口研究 室では, 1938 年頃から土井新次さん, 多田靖次さん, 朝井勇宣先生らが中心になって大勢で取り組み, 1941 年頃に 314 号菌が分離され, 全国で使われるようにな った。海軍, 陸軍の燃料僘や協和醱酵, 合同酒精, 武 田薬品などが取り組み, 防府や大船などに直径 $10 \mathrm{~m}$ 以上のタンクを数十基も作り, 発酵関係の大学卒業生 は技術将校として派遣された。

戦後, アセトン・ブタノール発酵はソルベント生産 のために暫くは続けられたが, やがて石油化学にその 座を譲ることになる。しかし, その後, この大規模発 酵生産のノウハウは抗生物質発酵やアミノ酸発酵へと 受け継がれ, 多くの優秀な研究者, 技術者が企業で活
躍することによって, 戦後の経済復興の一翼を担うこ とになった。

\section{（5）抗生物質発酵}

戦争中に, イギリスのチャーチル首相の肺炎がペニ シリンで治ったというニュースは日本でも報道された。 早速, 陸軍は「碧素委員会」を立ち上げて研究を強力 に推進した。坂口研究室もその有力なメンバーで, 1943 年には早くも棟方 博さん（その後, 大日本ビ ール）がペニシリンを生産する青カビを分離し, 報告 している。これは, 馬場慎一郎さん, 食糧研究所へ行 かれた中野政弘さん, そして有馬 啓先生へと受け継 がれて戦後の抗生物質研究の最盛期を迎えた。昭和 23 年, 有馬先生は, 新潟大学へ行かれた小笠原長宏 さんと紫外線照射で Penicillium chriosogenum Q-176 の白色変異株を得た。この菌株は, ペニシリン精製に 邪魔であった黄色色素をつくらず，しかもペニシリン 高生産株であったので, 広く日本中で使われた。ペニ シリン研究でもう一つ独創的な成果は, 村尾沢夫さん との共同になるぺニシリン・アミダーゼの発見である。 ペニシリナーゼは第 1 図に示す $\mathrm{NH}-\mathrm{CO}$ 結合を切 るが, 坂口, 村尾によってP. chriosogenumやB. cereus から発見されたアミダーゼはへで示した, ペ ニシリナーゼとは別のアミド結合を切り，6-アミノ ペニシラミン酸を生成する酵素であった。謹一郎は, ペニシリンの尾が切れるから「ペニシン」だと言って いた。6-アミノペニシラミン酸には抗菌性があり, 後年, この部位に化学的にいろいろなものを付けた合 成ペニシリン群の製造に道を拓いた酵素ペニシリン・ アシラーゼと同一のものかどうかは, 今となっては知 るよしもないが, 逆反応であるから可能性がある, と は元藤沢薬品に扔られた奥原正国さん, 佐々木 斉さ ん, 磯貝隆夫さんからのご教示である。ペニシリン・ アミダーゼの思いつきは不眠症でうつらうつらしてい る時に思いついたもので,「見落としというものはあ るものだ」と言っていた。その他にも多くの抗生物質 を発見したが，ご多分にもれず，実用化できたものは 少ない。しかし，このような研究によって育てられた 多くの優秀な研究者は, 武田, 藤沢, 三共といった製 薬会社や研究所で活躍し，わが国の薬品製造に大きな 進歩をもたらした。

\section{（6）イノシン酸製造法の発見}

これはヤマサ醬油の国中 明さんと共同で発見した 


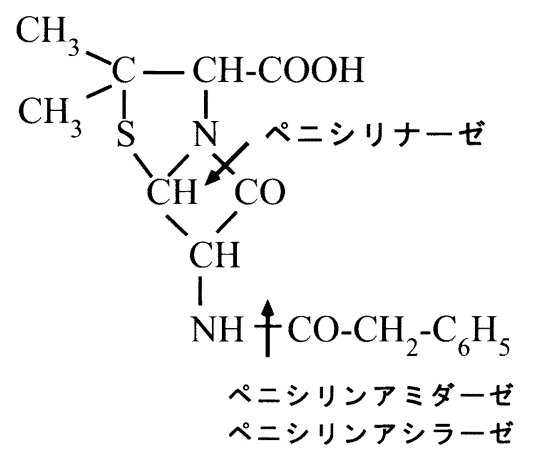

第 1 図 ペニシリンの酵素分解部位

もので，鰹節の旨味成分であるイノシン酸は核酸・ RNAの分解物中にあるはずなのにまだ見つかってい なかった。そこで国中さんに贅菌その他のカビの RNA 分解酵素を調べ，その分解物を必ず味わってみ るように言ったそうだ。なかなか呈味成分は見つから なかったが, 1960 年, 青力ビの一種, P. citrinumの RNA 分解酵素が 5 側を切ることを発見した。多くの RNA 分解酵素はアデニンーリボースの3’の位置に燐 酸のついた $3^{\prime}$-Adenine-nucleotide をつくり，5’の位 置に燐酸のついた 5'-Adenine - nucleotide（5'$\mathrm{AMP})$ をつるものは稀であった。国中さんはこの 5’-AMP に麦菌の AMP デアミナーゼを働かせ，目的 のイノシン酸，5-IMPをつくることに成功された。 同時に 5’-Guanine-nucleotide (5'GMP)，5’-キサンチ ル酸 (5XMP) も強い旨味を現し, 椎茸の味であろ うとされた。面白いことに，この様な味の成分は，そ れだけを舐めてもあまり強い旨さではなく，グルタミ ン酸ソーダと一緒に舐めると大変強い旨味となったそ うです。国中さんは初めは失望されたのだそうですが， 料理のダシのことを思いつかれたのでしょうか, グル

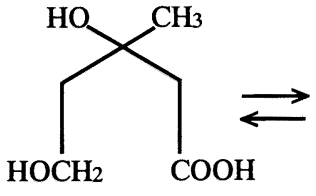

メバロン酸<smiles>CC1(O)CCOC(=O)C1</smiles>

火落酸 メバロラクトン
第 2 図 メバロン酸（火落酸）の構造

タミン酸ソーダと混ぜて強い旨味を感じ, 大いに喜ば れたそうです。よく思いつかれたと思います。

これは後に工業化されたことはよく知られている。 酵母の RNA を原料としたが，後に糖蜜から直接発酵 法でIMPやGMP を生産する方法も発見され, 発酵 工業の一翼を担うこととなった。

（7）火落酸の発見一メバロン酸と同一

田村學造先生は長い間，バイオアッセイでアミノ酸 や生長促進因子の研究をなさっていたが, 日本酒に火 落ちという一種の腐敗を生じさせるLactobacillus homohiochii と L. heterohiochii (現在は L. fructivorans）は日本酒中のある新物質がないと生育できな いこと，その物質が銤菌によって造られるものである ことを発見された。そして，その新物質を同定され， 化学構造も決定されていたが, 発表が遅れているうち に, Wright 等が同一物質をメバロン酸として, 1956 年にアメリカ化学雑誌に発表した。田村先生等も同年 の応微研の英文誌にヒオチ酸として発表された。この 新物質は，衆知のように，イソプレノイド骨格を持つ コレステロール，ビタミン $\mathrm{A}$, 多くの抗生物質, Coenzyme Q といった重要物質を造る基本物質であっ た。 